\title{
Формулювання вимог до захищеності бойових броньованих машин від ураження боєприпасами кінетичної дії
}

\author{
Яна Горбачова 1 А \\ А Національний університет оборони України імені Івана Черняховського, пр-кт Повітрофлотський, 28, г. Київ, 03049, Україна
}

Received: March 24, 2021 | Revised: April 22, 2021 | Accepted: April 30, 2021

DOI: $10.33445 /$ sds.2021.11.2.12

\begin{abstract}
Анотація
У статті наведено класифікацію уражень броньової перешкоди за тактичною ознакою та за характером деформації броньового матеріалу. Розглянуто, які ураження є безпечними та небезпечними. Надана характеристика ураженням, які відносяться до крихких та в'язких, від чого залежить їх утворення та в чому полягає їх суттєва відмінність. Визначено основні фактори, які впливають на характер ураження броньової перешкоди, а саме: твердість броньової перешкоди, відношення товщини броні до калібру боєприпасів, якість боєприпасів, якість броньової перешкоди і температурні умови обстрілу та надана їх характеристика. Також, визначено, як впливає форма головної частини боєприпасів та їх твердість і міцність на характер взаємодії з броньовою перешкодою. Розкрито, що мається на увазі під якістю броньової перешкоди та визначено основні дефекти додаткового захисту, які можуть суттєво впливати на зниження рівня захищеності бойових броньованих машин. Крім того, запропоновано процес вибору раціонального способу захисту бойової броньованої машини від боєприпасів кінетичної дії та для формалізації поставленого наукового завдання на основі теоретико-множинного підходу представлено модель стійкості броньової перешкоди. Виходячи із зазначеного наукового завдання, необхідно визначити таку стійкість броньової перешкоди при якій ії цільова функція набуває максимального значення серед усіх можливих варіантів.
\end{abstract}

Ключові слова: бойові броньовані машини, захищеність, боєприпаси кінетичної дії, броньована перешкода, класифікація уражень, показники стійкості.

\section{Постановка проблеми}

Досвід ведення бойових дій на сході нашої країни [1-4] підтверджує практичну дилему, за якою засоби ураження кінетичної дії та низький рівень захищеності бойових броньованих машин (ББМ) досить серйозно впливають на зміст оперативних рішень, що приймаються стосовно застосування військ (сил). Поряд із застосуванням артилерії, одним із найбільш ефективних способів ураження особового складу та бойової техніки $€$ застосування боєприпасів кінетичної дії. Отже, засоби ураження кінетичної дії є важливою складовою сучасних армій. За таких умов виникає потреба щодо забезпечення достатнього рівня захищеності ББМ від відповідних засобів ураження. Серед показників ефективності системи ураження $\epsilon$ показник дольової участі боєприпасів кінетичної дії у загальній системі вогневого ураження. Актуальність піднятого проблемного питання підтверджується досвідом дій підрозділів в операції Об'єднаних сил (ОOC).

\section{Аналіз останніх досліджень та публікацій}

Дослідженню питань захищеності зразків озброєння та військової техніки (ОВТ) від засобів ураження кінетичної дії під час ведення операції (бойових дій) присвячена ціла низка

\footnotetext{
${ }^{1}$ Corresponding author: ад’юнкт кафедри технічного забезпечення, e-mail: 2016drug@gmail.com, ORCID: 0000-0002-1652-2941
} 
робіт, як вітчизняних так і закордонних вчених, зокрема в роботі [5] визначено множину варіантів технічних рішень щодо підвищення рівня балістичної захищеності автомобілів багатоцільового призначення за групами декомпозиції їх конструкції, а у публікації [6] проведено аналіз застосування захисних пристроїв під час ведення бойових дій, які виготовляються у військах, силами екіпажів зразків ОВТ. На основі даного аналізу запропоновано варіант класифікації таких пристроїв та сконцентрована увага на необхідність вивчення досвіду їх застосування. В літературних джерелах [7] запропоновано підхід щодо вибору раціональної конструкції автомобіля багатоцільового призначення 3 підвищеним рівнем балістичної захищеності. Глибоке опрацювання цієї проблеми відображене у публікації [8] у якій для оцінювання відносних властивостей захисного екрану до уражаючої енергії засобів ураження проведено експериментальне дослідження, яке дозволило перевірити висунуту гіпотезу щодо застосування декількох слоїв матеріалів в захисних екранах для захисту ББМ від засобів ураження, які під дією кінетичної енергії руйнують броньову перешкоду. На основі отриманих даних під час експериментального дослідження побудовано математичну модель, яка описує імпульс пробиття захисного екрану. У роботі [9] досліджено вплив засобів ураження на базові колісні платформи. Для перевірки базових колісних платформ на стійкість до засобів ураження запропонована методика експериментального дослідження. На основі експериментальних даних, отриманих під час лабораторного дослідження, побудовано математичну модель впливу засобів ураження на базові колісні платформи. Окремі аспекти даної проблематики викладені у роботі [10], яка присвячена аналізу тенденцій розвитку ОВТ Сухопутних військ, а саме шляхам підвищення їх захищеності від засобів ураження. Розглянуто напрями розвитку та основні конструктивні особливості ОВТ щодо забезпечення захисту від засобів ураження. У публікації [11] порівняні розрахункові критерії броньової стійкості різних протикульних захисних матеріалів (броньової сталі, броньової кераміки) 3 отриманим зварюванням вибухом біметалом сталь-алюміній як матеріалом для двошарової броні. Оптимальним визнаний розрахунковий критерій Стігліца. Аналітичні дослідження різних методів визначення балістичної стійкості пластин індивідуальної броні визначено в роботі [12] та розглянуто основні етапи під час проникнення ударника в металеву пластину. Але в публікації не розроблена методика, яка 6 давала можливість оцінити опір сталі руйнуванню при проникненні діючого елемента $з$ урахуванням механізму процесу пробиття перешкоди. У літературному джерелі [13] запропонована методика обґрунтування рівня захищеності бойових колісних машин, що базується на визначенні кількості влучень у зразок під час його обстрілу з декількох засобів ураження. Вказана методика визначає середню кількість влучень у елементи зразка для обґрунтування технічних рішень щодо підвищення рівня його захисту. У публікації [14] розглянуто постановку завдання експериментального дослідження складового боєприпаса i програми випробувань для стрілецької зброї. А в зарубіжному виданні [15] наведені та проаналізовані системи пасивного захисту наступного покоління та обговорено створення нових систем захисту з мінімально можливою вагою (текстильні (ткані)) системи захисту за допомогою конструкції (сітки) $\mathrm{Q}-\mathrm{NET}$, що забезпечує максимальну продуктивність пасивного захисту в широкому діапазоні загроз та умов і під будь-яким кутом, і може бути використано по всьому транспортному засобу. у публікації [16] наведені приклади військових операцій армії США, під час яких замість відносно легких тактичних колісних транспортних засобів Типу 1 (ТКТЗ) використовувались більш захищені варіанти Типу 2, а пізніше й варіанти Типу 3. Аналіз результатів проведеної заміни показав, що за рахунок застосування ТКТЗ Типу 2 було зменшено летальні випадки серед особового складу та відвернуті збитки від втрати техніки в 
бойових піхотних підрозділах на суму від 1,1 до 24,6 мільйонів доларів, але при цьому витрати на проведення такої заміни перевищили граничний показник економічної ефективності в 7,5 мільйонів доларів.

Але в даних роботах не розглядалися та не враховувалися характеристики боєприпасів кінетичної дії та їх вплив на броньову перешкоду ББМ в залежності від факторів, що впливають на процес пробиття додаткового захисту.

\section{Постановка завдання}

Метою статті буде враховуючи характеристики боєприпасів кінетичної дії обґрунтувати вимоги до рівня захищеності ББМ, які нададуть можливість розробити та впровадити нові конструкторські рішення, цим самим забезпечити захищеність особового складу під час виконання завдань за призначенням.

\section{Виклад основного матеріалу}

Для визначення найбільш уразливих ділянок ББМ, необхідно розглянути їх конструктивні особливості, показники стійкості броньової перешкоди, показники боєприпасів кінетичної дії, які призводять до руйнування броньової перешкоди [17].

Ураження броньової перешкоди класифікуються за тактичною ознакою та за характером деформації броньового матеріалу.

За тактичною ознакою ураження діляться на небезпечні та безпечні. До небезпечних відносяться ураження, які визивають в поза броньовому об'ємі утворення осколків тильного шару броньової перешкоди або бронебійного засобу, а також виникнення імпульсивних акустичних хвиль, що призводять до травмування екіпажу і виходу 3 ладу обладнання та ББМ. Безпечні ураження не завдають шкоди екіпажу і не порушують нормальну роботу обладнання ББМ.

За характером деформації ураження діляться на в'язкі та крихкі. До в'язких уражень відносяться: прокол, пробка, а також пробоїна, яка утворюється в результаті впливу кумулятивної струї. До крихких уражень відносяться: відкол, розкол, пролом, а також ураження, що обумовлене впливом бронебійних боєприпасів. Таким чином, в'язкі ураження утворюються при пластичній деформації матеріалу броньової перешкоди, а крихкі ураження $\epsilon$ результатом переважно крихкого руйнування матеріалу перешкоди [18].

Класифікація уражень за характером деформації броньової перешкоди розкриває істотну відмінність в механізмі взаємодії бронебійних засобів 3 броневою перешкодою. В'язкі ураження утворюються при значній витраті енергії бронебійного засобу i, отже, кращі з точки зору стійкості броньового захисту. Крім того, в'язкі ураження по об'єму менші за крихкі і значно відрізняються від останніх більш високою ремонтопридатністю. Тому, при виготовленні броньової перешкоди необхідно прагнути до того, щоб комплекс властивостей броньових перешкод і броньових конструкцій визначав більш високу вірогідність утворення в'язких уражень, а не крихких при взаємодії з будьякими бронебійними засобами.

На характер ураження броньової перешкоди впливає велика кількість факторів, основними з яких $\epsilon$ твердість броньової перешкоди, відношення товщини броні до калібру боєприпасів, якість боєприпасів, якість броньової перешкоди i температурні умови обстрілу.

Твердість броньової перешкоди відіграє позитивну роль в забезпеченні стійкості, так як 3 підвищенням твердості підвищується опірність броньової перешкоди до проникнення боєприпасів. Крім того, підвищення твердості броньової перешкоди збільшує деформацію боєприпасів і 
призводить до їх руйнування, на що витрачається частина енергії боєприпасів. Але $з$ підвищенням твердості броньова перешкода стає більш крихкою, нездатною до пластичної деформації, так як її в'язкість і пластичність зменшуються, і при взаємодії $з$ боєприпасами може руйнуватися крихко, аж до розколювання.

Вплив твердості броньової перешкоди на її стійкість і характер ураження наочно пояснюється роботою [19], з якої слідує, що підвищення твердості броньової перешкоди призводить спочатку до збільшення ї̈ стійкості, а потім, в результаті переходу від в'язких уражень до крихких, до різкого зменшення стійкості броньової перешкоди. Підвищення твердості броньової перешкоди призводить до підвищення її стійкості тільки при утворенні в'язких уражень, причому більш суттєва залежність спостерігається при утворенні проколу. Це пояснюється тим, що утворення проколу відбувається при достатньому запасі пластичності броньової перешкоди і підвищення твердості в цих умовах не змінює характеру взаємодії. При подальшому підвищенні твердості запас пластичності вичерпується і характер ураження змінюється. За умови утворення пробки збільшення твердості до істотного підвищення стійкості не призводить, так як кільцева тріщина, що визначає створення пробки, створюється на більш ранній стадії взаємодії.

В умовах утворення крихких уражень підвищення твердості відіграє негативну роль.

Також, необхідно враховувати запропонований у роботі [19] підхід, який справедливий при ідентичних умовах випробувань (товщина і якість броні, калібр і форма боєприпасів тощо). Таким чином, для любих конкретних умов обстрілу існує оптимальне поєднання твердості і міцності 3 в'язкістю і пластичністю, при якій забезпечується найвища стійкість броньової перешкоди.

Відношення товщини броньової перешкоди $b$ до калібру боєприпасів $d$ має суттєвий вплив на характер взаємодії і на вид ураження, яке утворюється. Боєприпаси невеликого калібру, взаємодіючи з товстою броневою перешкодою $(b / d \geq 3)$, як правило, великих динамічних навантажень в броньовій перешкоді не викликають, тому в цих випадках найбільш вірогідним видом ураження $€$ прокол. Великі боєприпаси в тонкій броньовій перешкоді визивають, як правило, крихкі ураження: розкол або пролом $(b / d<0,3)$. Якщо ж товщина броньової перешкоди відповідає калібру снаряду $(b / d \approx 1)$, то найбільш вірогідним видом ураження в цьому випадку буде пробка.

Це пояснюється тим, що при більших значеннях $(b / d)$ основним видом напруги будуть напруження стискання (зминання), які призводять до утворення проколу. При невеликих значеннях $(b / d)$ в броні за рахунок значних динамічних навантажень виникають великі згинальні напруги, що призводять до крихких руйнувань.

Також істотний вплив на характер взаємодії з броневою перешкодою відіграє форма головної частини боєприпасів, які бувають гостроголовими і заокругленими, що мають на головній частині площини притуплення.

Гостроголові боєприпаси легше проколюють броньову перешкоду, так як проща контакту з броневою перешкодою збільшується поступово і в цих умовах переважають напруження стискання. Боєприпаси 3 округленням контактують 3 броневою перешкодою відразу по всій площині притуплення. При цьому різкі динамічні навантаження відразу ж призводять до утворення кільцевої тріщини в броньовій перешкоді, що в подальшому веде до зрізу пробки. Вірогідність отримання проколу тим більша, чим більше загострення головної частини боєприпасів.

Важливе значення мають твердість i міцність самих боєприпасів, від яких залежать руйнування його загостреної 
частини на ранніх стадіях процесу взаємодії. При ранньому спрацюванні головної частини боєприпасів відбувається взаємодія як 3 боєприпасами заокругленими і обумовлює утворення пробки.

Таким чином, бронебійна здатність гостроголових боєприпасів, як правило, вища при взаємодії з в'язкою і пластичною броневою перешкодою (середньої і низької твердості). Боєприпаси заокругленої форми краще уражають броню більш високої твердості.

Якість броньової перешкоди, під якою мається на увазі наявність технологічних дефектів, також суттєво впливає на характер ураження. До основних дефектів броньової перешкоди відносяться: шиферність, розшарування, стовпчастість і дефекти термічної обробки [20].

Шиферністю називають розкатані неметалічні включення (неметалічні прошарки) в металі, що утворюють площини послаблення в броньовій перешкоді. Шиферність притаманна катаній броньовій перешкоді і $\epsilon$ дефектом металургійного виробництва. В броньовій перешкоді, що уражена шиферністю, частіше за все утворюються відколи з тильної сторони перешкоди.

Розшарування являють собою розкатані бульбашки і пористість. Розшарування, так як і шиферність, утворюються в катаній броньовій перешкоді, в якій при виплавці і розливанні залишилась велика кількість газів. Вплив розшарувань на стійкість броньової перешкоди і характер ураження аналогічний до впливу шиферності.

Стовпчастість - дефект, притаманний литій броньовій перешкоді і являє собою сильно розвинену зону стовпчастих кристалів (“стовпів") в броньовій виливці.

Як відомо, сталева виливка має три зони: зону невеликих рівновісних кристалів і зону великих рівновісних кристалів, розміщених в центральній частині злитку. Стовпчасті кристали розміщуються ближче до поверхні відливки перпендикулярно до їі стінок.
Зв'язок між стовпчастими кристалами сильно послаблений, так як між ними знаходяться неметалеві прошарки. При влучанні боєприпасів в литій броньовій перешкоді звичайно утворюються тріщини між стовпчастими кристалами, що розміщені перпендикулярно поверхні броньової виливки. Характерним видом ураження литої броньової перешкоди $\epsilon$ пробка. Стійкість литої броньової перешкоди тим менша, чим більш розвинута стовпчастість.

Дефекти термічної обробки, зазвичай, призводять до зниження в'язкості i пластичності броньової перешкоди, а відповідно, до підвищення схильності до крихкого руйнування.

Температурні умови обстрілу броньової перешкоди надають деякий вплив на характер ураження, так як зміна температури металу викликає зміну його механічних властивостей. 3 підвищенням температури твердість зменшується, а пластичність і в'язкість - збільшуються. Тому, при підвищенні температури вірогідність утворення крихких уражень знижується. Однак стійкість броньової перешкоди 3 підвищенням температури може змінюватися в ту чи іншу сторону. Броньова перешкода в якої твердість $€$ основним фактором, що визначає ії стійкість (протикульова броньова перешкода високої твердості), влітку показує знижену стійкість. Протикульова броньова перешкода (середньої і низької твердості) при обстрілі взимку може знизити стійкість за рахунок утворення більш крихких уражень.

Дійсні значення стійкості необхідно знати при розрахунку броньованих перешкод та проектуванні броньованої конструкцій. Так, як характер навантаження броньової перешкоди при взаємодії з бронебійними засобами сильно відрізняється від умов статичного навантаження зразків при механічних випробуваннях, то за механічними властивостями матеріалу броньової перешкоди судити про його стійкість $€$ недоцільним. Тому, найбільш 
достовірні відомості про стійкість броньової перешкоди можна отримати тільки за допомогою обстрілу, при якому про стійкість броньової перешкоди судять за спеціальними параметрами, що визначаються в процесі досліду.

Вибір захисту ББМ від боєприпасів кінетичної дії передбачає вирішення невідповідностей стійкості броньової перешкоди до засобів ураження, тобто від боєприпасів кінетичної дії при існуючому способі захисту $S_{i с н}: Q_{\text {брон }}>>Q_{\sigma . n}$. Для його вирішення необхідно вибрати раціональний спосіб захисту $p$ ББМ $p \in P$ від боєприпасів кінетичної дії, з $P$ - множини припустимих рішень (способів).

Для формалізації поставленого наукового завдання на основі теоретико-множинного підходу представлено модель стійкості броньової перешкоди, як :

$$
Q=\left\langle H, b, \lambda, T, X, D, R(h), V, d, l, H_{6 . \Pi}, k\right\rangle,
$$

де $Q$ - стійкість броньової перешкоди;

$H$ - твердість броньової перешкоди;

$b$ - товщина броньової перешкоди;

$\lambda$ - кут зустрічі броньової перешкоди 3 засобами ураження кінетичної дії;

$T$ - температурні умови;

$X$ - хімічний склад броньової перешкоди;

$D$ - дефекти броньової перешкоди

$R(h)$ - зусилля проколу броньової перешкоди;

\section{Висновки}

Для отримання всебічних даних про якість броньової перешкоди i для визначення оптимального поєднання твердості і міцності 3 пластичністю і в'язкістю необхідні випробування броньової перешкоди обстрілом за різних температурних умов.

Різноманіття факторів, що визначають вид ураження і стійкість броньової перешкоди, а також змінний характер впливу різних факторів протягом одного процесу взаємодії
$V$ - швидкість боєприпасів кінетичної дії;

$d$-калібр боєприпасів;

$l$ - відстань $з$ якої вистрілюють боєприпаси кінетичної дії;

$H_{6 . п}-$ твердість боєприпасів;

$k$ - форма головної частини боєприпасів.

Стійкість броньової перешкоди може бути подана у вигляді відображення:

$H \times b \times \lambda \times T \times X \times D \rightarrow E^{*}$ при $D \rightarrow \min$

Однією з основних вимог, які висуваються до стійкості броньової перешкоди, $є$ вимога щодо протидії енергії боєприпасів $E_{6 . п}$. Тобто, під час взаємодії боєприпасів з броньовою перешкодою енергія проколу повинна знизитись до рівня який не дозволить пробиття броньової перешкоди.

Тобто, у формалізованому вигляді завдання може бути представлено, як

$$
E_{\text {б.п }}\left(V, d, l, H_{6 . \Pi}, k\right) \rightarrow \min ;
$$

при

$$
\begin{gathered}
E \geq E^{*}, H \geq H^{*}, b \geq b^{*}, \lambda \geq \lambda^{*}, T \geq T^{*}, R(h) \\
\geq R(h)^{*}
\end{gathered}
$$

де $E^{*}, H^{*}, b^{*}, \lambda^{*}, T^{*}, R(h)^{*}$ - деякі граничні показники стійкості броньової перешкоди.

Отже, деталізуючи сформульоване наукове завдання, необхідно визначити таку стійкість показників броньової перешкоди при якій ії цільова функція набуває максимального значення серед всіх можливих варіантів.

обумовлюють необхідність глибокого і всебічного вивчення механізму взаємодії боєприпасів і броньової перешкоди на різних стадіях процесу взаємодії.

В подальшому, на основі теоретичних досліджень необхідно розробити методику оцінювання стійкості броньової перешкоди до вражаючих факторів боєприпасів кінетичної дії.

\section{Список використаних джерел}

1. Аналіз бойових дій в районі Іловайська після вторгнення російських військ 24-29 серпня 2014 року. URL: http://www.mil.gov.ua/news/2015/10/19/a 
naliz-illovausk--14354/.

2. Аналіз бойових дій на сході України в ході зимової кампанії 2014-2015 років. URL: http://www.mil.gov.ua/news/2015/12

/23/analiz-bojovih-dij-na-shodi-ukraini-vhodi-zimovoi-kampanii-2014-2015-rokiv-$16785 /$.

3. Аналіз Генерального штабу ЗС України щодо бойових дій на Дебальцевському плацдармі з 27 січня до 18 лютого 2015 року.

URL:

http://www.mil.gov.ua/analitichni-

materiali/analiz-generalnogo-shtabu-zsushhodo-bojovih-dij-na-debalczevskomuplaczdarmi-z-27-sichnya-do-18-lyutogo2015-roku.html.

4. Аналіз ведення АТО та наслідків вторгнення РФ в Україну у серпні-вересні 2014 року. URL: https://www.slideshare.net/tsnua/201451587585

5. Гребеник О. М. Щодо питання підвищення захищеності військової автомобільної техніки. Збірник наукових праць Центру воєнно-стратегічних досліджень Національного університету оборони України. 2013. № 1(47). С. 77-81.

6. Брель М. П. Анализ применения нестандартних защитных устройств для боевых бронированных машин. Сборник научных статей военной академии Республики Беларусь. 2018. № 34. С. 127134.

7. Гребеник О. М. Методика вибору раціональної конструкції автомобіля багатоцільового призначення 3 підвищеним рівнем балістичної захищеності. Науково-виробничий журнал. 2013. № 2 (232). С. 22-24.

8. Дачковський В. О., Даценко І. П., Коцюруба В. І., Яльницький О. Д., Голда О. Л., Неділько О. М., Сиротенко А. М. Експериментальне дослідження впливу засобів ураження на захисні екрани бойових броньованих машин. Опір матеріалів і теорія споруд: наук.-тех. збірн. К.: КНУБА, 2020. Вип. 104. С. 117-135.
9. Куртсеітов Т. Л., Дачковський В. О., Кізяк Я. О., Угринович О. І. Експериментальне дослідження стійкості базових колісних платформ до впливу вибухонебезпечних предметів. Natural, Mathematical and Technical science NaMaTech. 2018, Held in Budapest on 16th of December 2018. DOI: 10.31174/SEND-NT2018-186VI22-15.

10. Лисий М., Мисик А., Дачковський В., Горбачова Я. Напрямки розвитку озброєння та військової техніки щодо підвищення рівня захищеності. Збірник наукових праць Національної академії Державної прикордонної служби України Серія: військові та технічні науки. 2019. № 3 (87). C. 411-428. DOI: 10.32453/3.V81i3.483.

11. Загорянський В. Г. Обоснование применимости биметалла стальалюминий по расчетным критериям противопульной бронестойкости. Вісник НТУУ "КПІ". Серія: машинобудування. Кременчуг. № 3 (75). 2015. С. 37-41.

12. Перчун Г. І., Самофалова А. О., Кононенко Г. А. Методи визначення балістичної стійкості пластин броні. Фундаментальные и прикладные проблемы черной металургии: сб. научн. трудов.Дніпропетровськ. ІЧМ НАН України. 2015. Вип. 30. С. 337-342.

13. Голуб В. А. Методика обгрунтування рівня захищеності бойових колісних машин. Системи озброєння і військова техніка. Київ: ЦНДІ ОВТ ЗС України. 2013. № 3 (35). С. 9-12.

14. Антипко О. Б., Бирюков И. Ю., Сыщук С. И., Щепцов A. В. Постановка задачи экспериментального исследования составного боеприпаса и программа испытаний для стрелкового оружия. Система озброєння і військова техніка. 2016. № 1 (45). C.10-13.

15. Advances in RPG Protection Technology. NextGeneration Passive RPG Protection Systems Adapting to the Evolving Threat of the RPG Investing in New Technologies The Future of RPG Protection Assessing the Next 
Generation of RPG Protection Special report. $18 \quad$ U. https://issuu.com/globalbusinessmedia.org/docs /defence_industry_reports_105/.

16. Chris Rohlfs, Ryan Sullivan. The costeffectiveness of armored tactical wheeled vehicles for overseas us army operations. Center for Policy Research, Syracuse University, Syracuse, NY, USA; ${ }^{b}$ Defense Resources Management Institute, Naval Postgraduate School, Monterey, CA, USA (Received 14 April 2012; in final form 25 July 2012). Defence and Peace Economics, 2013. Vol. 24, No. 4, P. 293-316. DOI: 10.1080/10242694.2012.723158.

17. Дачковський В. О. Методика визначення характеристик живучості озброєння та військової техніки. Social development \& Security. 2020. №10(1), 18-24. DOI: 10.33445/sds.2020.10.1.3

18. David Roylance. Mechanical properties of materials.2008. 128 p. URL: www.academia.edu/3891515.

19. Пашков П.О. Разрыв металов. Ленинград: Судпромгиз. 1960. 243 с.

20. Пашков П.О. Пластичность и разрушение металов. Ленинград: Судпромгиз. 1949. 259 c.

21. Кобылкин И. Ф., Селиванов В. В. Материалы и структуры легкой бронезащиты: учебник. М: Издательство МГТУ им. Н.Э. Баумана. 2014. 191 с.

\title{
Формулирование требований к защищенности боевых бронированных машин от поражения боеприпасами кинетического действия
}

\author{
Яна Горбачева ${ }^{1 \mathrm{~A}}$ \\ ${ }^{1}$ Corresponding author: адъюнкт кафедры технического обеспечения, e-mail: 2016drug@gmail.com, ORCID: 0000-0002-1652-2941

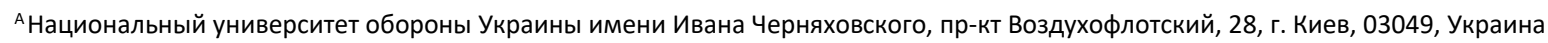

\begin{abstract}
Аннотация
В статье приведена классификация поражений броневой преграды по тактическому признаку и по характеру деформации броневого материала. Рассмотрены, какие поражения являются безопасными и опасными. Дана характеристика поражением, которые относятся к хрупким и вязких, от чего зависит их образование и в чем заключается их существенное отличие. Определены основные факторы, влияющие на характер поражения броневой преграды, а именно: твердость броневой преграды, отношение толщины брони до калибра боеприпасов, качество боеприпасов, качество броневой преграды и температурные условия обстрела и предоставлена их характеристика. Также определено, как влияет форма головной части боеприпасов и их твердость, и прочность на характер взаимодействия с броневым препятствием. Раскрыто, что подразумевается под качеством броневой преграды и определены основные дефекты дополнительной защиты, которые могут существенно влиять на снижение уровня защищенности боевых бронированных машин. Кроме того, предложено процесс выбора рационального способа защиты боевой бронированной машины от боеприпасов кинетического действия и для формализации поставленной научной задачи на основе теоретико-множественного подхода представлена модель устойчивости броневой преграды. Исходя из указанной научной задачи, необходимо определить такую устойчивость броневой преграды, при которой ее целевая функция принимает максимальное значение среди всех возможных вариантов.
\end{abstract}

Ключевые слова: боевые бронированные машины, защищенность, боеприпасы кинетического действия, броневое препятствие, классификация поражений, показатели устойчивости. 


\title{
Formulation of requirements for the protection of armored combat vehicles from damage by kinetic ammunition
}

\author{
Yana Horbachova ${ }^{1 \mathrm{~A}}$ \\ ${ }^{1}$ Corresponding author: PhD student Department of Technical Support, e-mail: 2016drug@gmail.com, ORCID: 0000-0002-1652-2941 \\ A National Defence University of Ukraine named Ivan Chernyiakhovskyi, 28 Povitroflotsky Ave., Kyiv, 03049
}

\begin{abstract}
The article presents the classification of armor barrier lesions according to the tactical feature and the nature of the deformation of the armor material. The lesions are considered safe and dangerous. The characteristics of the lesions, which are fragile and viscous, are given, on what their formation depends and what is their essential difference. The main factors influencing the nature of the damage to the armor barrier are identified, namely: the hardness of the armor barrier, the ratio of armor thickness to ammunition caliber, ammunition quality, armor barrier quality and temperature conditions and their characteristics. Also, it is determined how the shape of the main part of the ammunition and their hardness and strength affect the nature of interaction with the armor barrier. It is revealed what is meant by the quality of the armor barrier and the main defects of additional protection are identified, which can significantly affect the level of protection of armored combat vehicles. In addition, the process of choosing a rational way to protect an armored combat vehicle from kinetic ammunition is proposed, and a model of armor obstacle stability is presented to formalize the set scientific task on the basis of a settheoretic approach. Based on this scientific task, it is necessary to determine the stability of the armor barrier at which its target function acquires the maximum value among all possible options.
\end{abstract}

Keywords: armored combat vehicles, security, kinetic ammunition, armored obstacle, classification of damage, stability indicators.

\section{References}

1. Analysis of hostilities in the llovaisk region after the invasion of Russian troops on August 24-29, 2014. Available from: Http://www.mil.gov.ua/news/2015/10/19/a naliz-illovausk--14354/

2. Analysis of hostilities in eastern Ukraine during the winter campaign of 2014-2015. Available from:

http://www.mil.gov.ua/news/2015/12

/23/analiz-bojovih-dij-na-shodi-ukraini-vhodi-zimovoi-kampanii-2014-2015-rokiv-16785/

3. Analysis of the General Staff of the Armed Forces of Ukraine on hostilities at the Debaltseve bridgehead from January 27 to February 18, 2015. Available from: http://www.mil.gov.ua/analitichnimateriali/analiz-generalnogo-shtabu-zsushhodo-bojovih-dij-na-debalczevskomu- placzdarmi-z-27-sichnya-do-18-lyutogo2015-roku.html.

4. Analysis of the anti-terrorist operation and the consequences of the Russian invasion of Ukraine in August-September 2014. Available from: https://www.slideshare.net/tsnua/ 2014-51587585

5. Grebenik O.M. Nutritional support for the seizure of modern automotive technology. Zbirnik naukovykh prats to the Center for Military Strategic Advocates of the National University of Defense of Ukraine. 2013. No. 1 (47). p. 77-81.

6. Brel M.P. Analysis of the use of non-standard protective devices for armored combat vehicles. Collection of scientific articles of the Military Academy of the Republic of Belarus. 2018. № 34. p. 127-134.

7. Grebenik O.M The method of vibrating the 
rational design of a car of a high-quality design with an increase in balistic protection. Science-virobnichesky journal. 2013. No. 2 (232). p. 22-24.

8. Dachkovskyi, V., Datsenko, I., Kotsiuruba, V., Yalnytskyi, O., Holda, O., Nedilko, O., Syrotenko, A. Experimental investigation of impact of injury measures on the protection screens of combat armoured vehicles. Strength of Materials and Theory of Structures. 2020, No. 104, p. 117-135. DOI: 10.32347/2410-2547.2020.104.117-135

9. Kurtseitov, T., Dachkovskyi, V., Kizyak, Y., Uhrynovych, O. Experimental study of stability of base wheel platforms to the influence of explosive objects. Natural, Mathematical and Technical science NaMaTech. 2018, Held in Budapest on 16th of December 2018. DOI: 10.31174/SENDNT2018-186VI22-15

10. Lysyi M., Mysyk A., Dachkovskyi V., Horbachova Y. Development directions of arms and military equipment about increasing the security level. Collection of scientific works of the National Academy of State Border Guard Service of Ukraine. Series: military and technical sciences. 2019. $\begin{array}{lllll}\text { № } 3 & \text { (87). } & \text { P. } & 411-428 . & \text { DOI: }\end{array}$ 10.32453/3.V81i3.483.

11. Zagoryansky V. G. Illumination of steelaluminum bimetal by the calculated criteria of antitumor armor resistance. Bulletin of NTUU "KPI". Series: mechanical engineering. Kremenchug. № 3 (75). 2015. P. 37-41.

12. Perchun G. I., Samofalova A. O., Kononenko G. A. Methods for determining the ballistic stability of armor plates. Fundamental and applied problems of ferrous metallurgy: Sat. scientific works. Dnipropetrovsk. HMI NAS of Ukraine. 2015. Vip. 30. P. 337-342.

13. Golub V. A. Methods of substantiation of the level of protection of combat wheeled vehicles. Weapons systems and military equipment. Kyiv: Central Research Institute of Armed Forces of Ukraine. 2013. № 3 (35). P.9-12.

14. Antipko O. B., Birukov I. Y., Suchuk S. I., Chepcov A. B. Statement of the problem of experimental research of composite ammunition and test program for small arms. Weapons system and military equipment. 2016. № 1 (45). P.10-13.

15. Advances in RPG Protection Technology. Next-Generation Passive RPG Protection Systems Adapting to the Evolving Threat of the RPG Investing in New Technologies The Future of RPG Protection Assessing the Next Generation of RPG Protection Special report. 18 p. Available from: https://issuu.com/globalbusinessmedia.org/ docs/defence_industry_reports_105.

16. Rohlfs C., Sullivan R. The cost-effectiveness of armored tactical wheeled vehicles for overseas us army operations. aCenter for Policy Research, Syracuse University, Syracuse, NY, USA; bDefense Resources Management Institute, Naval Postgraduate School, Monterey, CA, USA (Received 14 April 2012; in final form 25 July 2012). Defence and Peace Economics, 2013. Vol. 24, No. 4, P. 293316. DOI: $10.1080 / 10242694.2012 .723158$.

17. Dachkovskyi V.O. Method of determination of survival characteristics of weapons and military equipment. Social development \& Security. 2020. №10(1), 18-24. DOI: 10.33445/sds.2020.10.1.3

18. Roylance D. Mechanical properties of materials. 2008. 128 p. Available from: www.academia.edu/3891515.

19. Pashkov P.O. Rupture of metals. Leningrad: Sudpromgiz. 1960. 243 p.

20. Pashkov P.O. Plasticity and destruction of metals. Leningrad: Sudpromgiz. 1949. 259 p.

21. Kobylkin I.F., Selivanov V.V. Materials and structures of light body armor: textbook. Moscow: Publishing house of MSTU im. N.E. Bauman. $2014.191 \mathrm{~s}$. 